\title{
SPRAIN OF THE PISIFORM-TRIQUETRAL JOINT
}

\author{
Report of Six Cases \\ A. McEwen Smith, Nottingham, England \\ Formerly Senior Surgical Registrar, Edinburgh Royal Infirmary
}

Perhaps the least satisfactory diagnosis in painful conditions of the wrist is that of tenosynovitis. In the first four patients in this series a diagnosis of tenosynovitis of the flexor carpi ulnaris was made, but their failure to respond to the usual conservative measures stimulated further investigation. The tests herein described, and the response to operative fusion, suggest that sprain of the pisiform-triquetral joint is the true pathology of this uncommon condition.

\section{CLINICAL FEATURES}

Six patients suffering from persistent pain in the region of the pisiform bone were seen in a busy surgical out-patient department during a period of two years. The pain was described as aching in character, and was either brought on or made worse by exertion, especially heavy lifting. The insertion of flexor carpi ulnaris was indicated as the site of greatest pain.

TABLE I

SUMMARY OF CASES

\begin{tabular}{|c|c|c|c|c|c|c|c|}
\hline Case & Age & $\begin{array}{l}\text { Duration of } \\
\text { symptoms }\end{array}$ & $\begin{array}{c}\text { Side } \\
\text { affected }\end{array}$ & $\begin{array}{c}\text { Mode of } \\
\text { onset }\end{array}$ & Treatment & Result & $\begin{array}{l}\text { Date } \\
\text { last seen }\end{array}$ \\
\hline 1 & 18 & 2 years & Right & Insidious & $\begin{array}{l}\text { Plaster } 2 \text { months } \\
\text { Exploration } 15.8 .50 \\
\text { Re-exploration } 22.6 .51 \\
\text { Fusion without internal fixa- } \\
\text { tion } 24.10 .51 \\
\text { Excision of pisiform } 10.11 .52\end{array}$ & $\begin{array}{l}\text { No relief } \\
\text { Relieved for } 3 \text { months } \\
\text { Temporary improvement } \\
\text { Painful fibrous union } \\
\text { Relieved }\end{array}$ & 6.1 .53 \\
\hline 2 & 28 & 1 year & Right & Followed & $\begin{array}{l}\text { Plaster } 10 \text { weeks } \\
\text { Excision of pisiform 24.1.50 }\end{array}$ & $\begin{array}{l}\text { No improvement } \\
\text { Relieved }\end{array}$ & 24.12 .52 \\
\hline 3 & 20 & 1 year & Left & Insidious & $\begin{array}{l}\text { Plaster } 4 \text { weeks } \\
\text { Operation refused } 10.4 .51\end{array}$ & | Temporary improvement & 29.8 .52 \\
\hline 4 & 30 & 3 weeks & Right & $\begin{array}{c}\text { Followed } \\
\text { fall }\end{array}$ & $\begin{array}{l}\text { Plaster } 6 \text { weeks } \\
\text { Fusion with internal fixation } \\
\quad 31.4 .52\end{array}$ & $\begin{array}{l}\text { No improvement } \\
\text { Relieved }\end{array}$ & 13.8.52 \\
\hline 5 & 28 & 3 months & Left & $\begin{array}{l}\text { Blow on } \\
\text { wrist }\end{array}$ & $\begin{array}{l}\text { Fusion with internal fixation } \\
\text { 30.11.51 }\end{array}$ & Relieved & 5.11 .52 \\
\hline 6 & 18 & 4 years & Right & $\begin{array}{l}\text { Blow on } \\
\text { wrist }\end{array}$ & $\begin{array}{l}\text { Fusion with internal fixation } \\
30.11 .51\end{array}$ & Relieved & 4.9 .52 \\
\hline
\end{tabular}

All six patients were women between the ages of eighteen and thirty, and the dominant hand was affected in each one. Four patients gave a history of injury, two from a fall and two from a direct blow on the front of the wrist. Three patients had pain referred to the fifth finger, and a fourth complained of weakness of the medial two fingers on heavy lifting. The clinical features are summarised in Table I. The disability tended to be most severe in the manual workers but interfered with work in all patients except in Case 3. In Case 4 the pain was so severe that the patient was unable to lift a teapot.

On clinical examination a constant finding was pain on resisted flexion of the wrist, 
greatest in the position of ulnar deviation. Pain was also elicited when the patient held a heary object in the outstretched hand with the forearm in full supination. In both these tests the pain was centred round the pisiform bone, and this suggested that the flexor carpi ulnaris insertion was the probable site of the lesion. More accurate localisation of the source of the pain followed the discovery that passive movement of the pisiform bone on the triquetrum elicited pain of the same character as that complained of. The pisiform can normally be displaced laterally on the triquetrum in the position of ulnar deviation of the hand when the muscles are relaxed. Pain on this test is diagnostic of sprain of the pisotripuetral joint, and in two cases movement was accompanied by crepitus. Three patients who were given an injection of local anaesthetic into the affected joint had relief of pain for the duration of the anaesthesia. In none of these patients did radiological examination reveal any abnormality.

\section{TREATMENT}

In riew of the chronicity of the condition and its failure to respond to prolonged immobilisation and physiotherapy, operative intervention seemed to be indicated. In (ase I

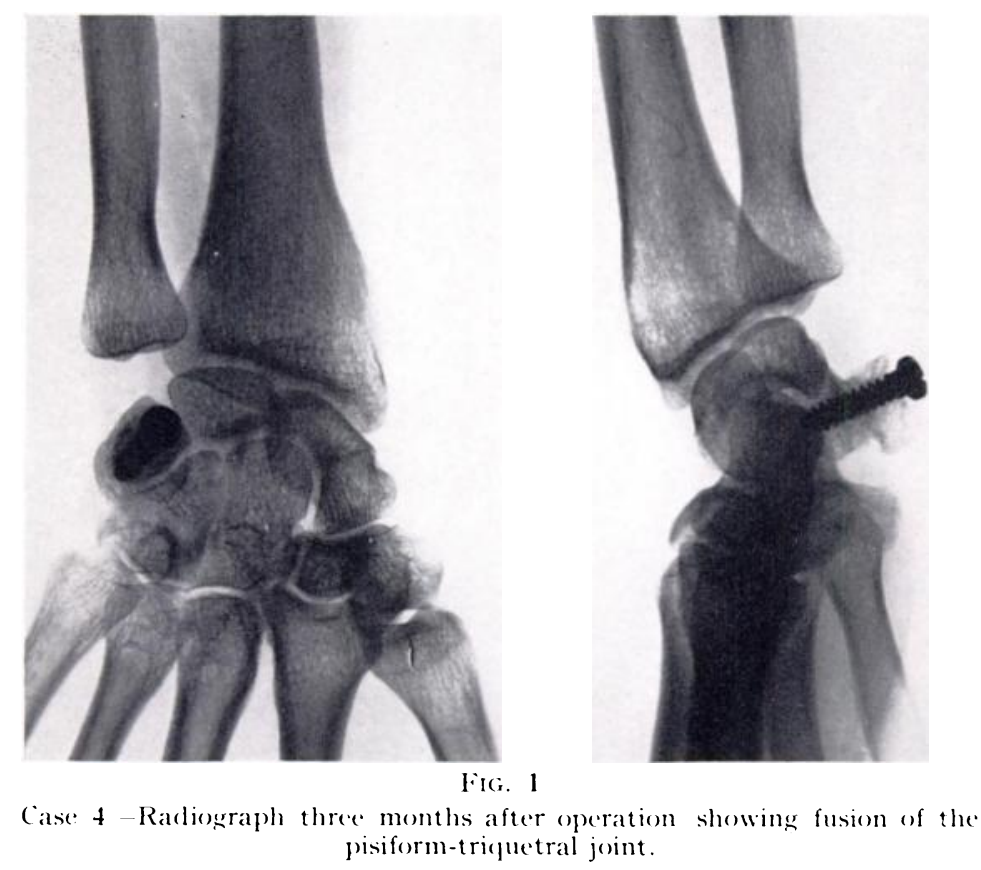

two attempts were made to rest the affected joint by dividing the tendinous slip attaching flexor carpi ulnaris to the pisiform, leaving the tendon to glide freely over the bone. Temporary relief of up to three months followed, but in both cases the symptoms recurred. Therefore in Case I arthrodesis of the pisiform-triepetral joint was undertaken. The joint surfaces were simply excised, and no internal fixation was used, for it was hoped to avoid inserting a metallic foreign bedy in such close proximity to the wrist joint. But the operation led to a painful fibrous union and ultimately the pisiform was excised with relief. In (ase 2 the pisiform was excised. The final result was good but recovery was delaved by involvement of the ulnar nerve in scar tissue, which necessitated a second operation for its relief.

In (ase 3 the symptoms were considered to be severe enough to justify operation but the patient refused it. Temporary improvement followed immobilisation in plaster for one month. When seen sixteen months later she continued to have pain which was worse after carrying, lifting, and riding a bicycle.

In (ases 4,5 , and $f$ treatment was by excision of the joint surfaces and internal fixation

NO.. 36 B, No. 4, NONEMBER 1954 
by a metal screw. In all three patients the symptoms were completely relieved. In (ase i) the screw became loose and was removed nine months after operation, but fusion remained firm and the patient continued to do heary work on a farm.

Technique of operation - The joint is approached from the lateral side and the exposed articular cartilages are excised. The pisiform is drilled through its exact centre to avoid splitting the bone, and the drill continued into the triquetrum. A screw of sufficient length to penetrate the triquetrum to a depth equal to that of the pisiform is chosen. After operation the wrist joint is immobilised in plaster for seven weeks.

Results-All three patients returned to work in under three months. Figure I shows the

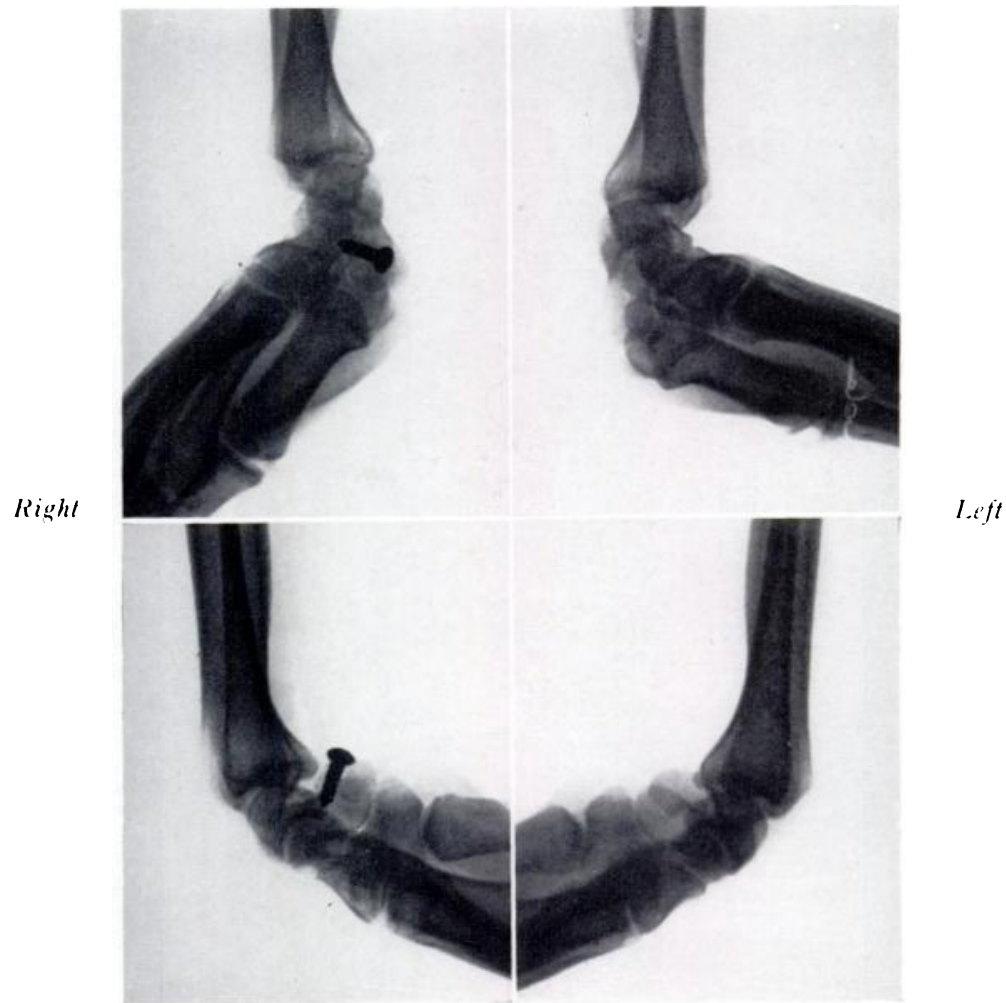

FIG. 2

Case 6-Comparative movement at both wrists three months after operation. Note slight limitation of extension at the right wrist.

result three and a half months after operation in Case 4. Fusion of the pisiform results in slight limitation of dorsiflexion of the wrist (Fig. 2). Histological examination of the excised cartilage, capsule, and synovial membrane revealed no gross pathology:

\section{DISGUSSION}

Wood Jones (1941) analysed the function of the flexor carpi ulnaris muscle, which may act as a prime mover, antagonist, synergist, or fixation muscle. In its latter capacity it acts as a special fixation muscle of the pisiform for the action of abductor digiti quinti, and as one of the fixation muscles of the wrist joint. It differs, however, from the other fixation muscles of the wrist in that it gains partial insertion into a joint. This joint, the pisiformtriquetral, has a separate synovial cavity surrounded by a thick capsule in the shape of a narrow ring. The joint permits passive movement in a lateral direction and active movement proximo-distally. Both these movements are greatest in the position of ulnar deviation, 
when the accessory ligaments of the pisiform bone, namely the transverse carpal, piso-hamate, and piso-metacarpal, are relaxed. Distally the pisiform bone gives origin directly to the abductor digiti quinti and indirectly to the short flexor and opponens muscles through their attachment to the flexor retinaculum. In the act of lifting with the forearm supinated the pisiform bone tends to be pulled distally by the hypothenar group of muscles. This tendency is resisted by its special fixation muscle, the flexor carpi ulnaris; but the pull of these muscles is approximately opposite only in full radial deviation of the hand. In any position between this and full ulnar deviation the pisiform is pulled on by its opposing muscles at an angle. Thus the force of the opposing muscular pull is thrown increasingly on the capsule of the piso-triquetral joint. If this capsule is weak a chronic sprain might be expected.

It is considered that the range of movement possessed by the pisiform bone prevents adequate immobilisation by the ordinary methods of plaster fixation. Treatment in a plaster for periods of up to two and a half months failed to relieve the condition in the four patients in whom it was tried. Thus a synovitis of the joint induced by injury might fail to resolve because of inadequate immobilisation and so become chronic. Alternatively in the four patients who gave a history of injury the trauma may merely have precipitated symptoms in a joint where weakness of the capsule predisposes it to sprain. This conception of the pathology is supported by the sex incidence and the relief produced by the injection of local anaesthetic into the joint and by the operative procedures described. On the basis of this pathology the only treatment likely to relieve the pain permanently and make the wrist capable of withstanding heavy strain is a fusion of the pisiform-triquetral joint. Although excision of the pisiform gives equal relief it removes one of the pillars of the flexor retinaculum and may expose the ulnar nerve to pressure. Furthermore it is an irrevocable procedure.

A search of the literature has yielded only one reference to the condition here described. Cyriax (1947) referred briefly to a sprain of the flexor carpi ulnaris insertion, which he treated by deep massage. He commented that treatment had to be prolonged and that it was so painful both to the patient and to the physiotherapist that it could be given only once a week. Dupont (1946) described a case of painless bilateral ligamentous laxity of the pisiform in a girl of twelve. Osteochondritis of the pisiform in a boy aged twelve has been described by Schmier and Meyers (1939). Phalen (1952) reported four cases of calcification adjacent to the pisiform in older patients. Jenkins (1951) described three patients of fifty and over with osteoarthritis of the pisiform-triquetral joint. All three patients were treated by excision of the pisiform bone; in two preliminary immobilisation in plaster had failed to alleviate the symptoms.

\section{SUMMARY}

Sprain of the pisiform triquetral joint is a definite clinical entity. It presents as a "tenosynovitis" of the flexor carpi ulnaris muscle from which it can be distinguished by the tests described. The disability in most cases is such that operation is justifiable. Fusion of the pisiform-triquetral joint is preferred to excision of the pisiform because it restores stability to the wrist with the least disturbance to related structures.

I wish to thank Mr Hector W. Porter for permission to investigate these patients, and Professor Walter Mercer for his help and advice.

\section{REFERENCES}

Cyriax, J. (1947): Rheumatism and Soft Tissue Injuries. London: Hamish Hamilton Medical Books. Dupont, R. (1946) : Laxité ligamentaire bilatérale du pisiforme. Revue d'Orthopédie, 32, 260.

Jenkins, S. A. (1951): Osteoarthritis of the Pisiform-Triquetral Joint. Journal of Bone and Joint Surgery, 33-B, 532.

Jones, F. Wood (1941): The Principles of Anatomy as seen in the Hand. Second edition. London: Baillière, Tindall, and Cox.

Phalen, G. S. (1952): Calcification Adjacent to the Pisiform Bone. Journal of Bone and Joint Surgery, 34-A, 579.

Schmier, A. A., and Meyers, M. P. (1939): Bilateral Osteochondritis of the Pisiform. Journal of Bone and Joint Surgery, 21, 789.

vol. 36 B, No. 4, November 1954 